Proceedings

\title{
Study of CAI system for basic physics operating with an internet
}

\section{インターネット環境で運用できる基礎物理学 $\mathrm{CAI}$ 教育システムの研究}

\author{
Shigeyuki TANAKA, Masato HOSOKAWA and Tsunenori SUZUKI \\ Department of Physics, Faculty of Science, Tokai University, 1117 Kitakaname, \\ Hiratsuka, Kanagawa, 259-12 JAPAN, TEL:81-463-58-1211 (EX. 3680) \\ ( Accepted for publication 8 November 1996 )
}

A Computer Aided Instruction system for basic physics was developed considering the trend towards international has been improved the understanding ability, and increased interest through our research. As next century education, we have a view the system works throughout all over the world over the limit of time.

Keywords: Internet, CAI, basic physics, Multimedia

\section{INTRODUCTION}

世界中の企業や大学のネットワークは相互につな がれ、WWWより最新情報を簡単に発信し、かつ受 信することができるようになった。21世紀の初頭の 情報環境は、インターネットや衛星放送などを用い たワールドなネットワークが整い、距離や場所、時 間に依存しない情報伝達が可能であろう。そのよう な環境を利用した教育は多様化した価值観を持つ世 代に対しての適合性など新しい可能性を秘めている。

著者らは、1993年度よりコンピュータを用いた、 理工学部系の基礎物理教育を「CAI物理学」として 実施してきた。その結果、「能動的な学習による教 育効果の向上」と「映像など視覚化による物理現象 への興味」といった、現代の学生に適合した教育方 法の 1 つであると報告された。

本研究は、インターネットを用いた教育方法の 1 つとして、ワールドなネットワーク規模での物理教 育システムの構築を目指し、その可能性と問題点に ついて検討した。

\section{SYSTEM DEVELOPMENT}

本研究はこのWWW使用したインターネットで運 用できるCAI教育システムの開発と研究を行った。

開発には「HTML」言語と「JavaScript」を使用し て行った。後者はクラスや継承がないことや、変数 を型宣言なしに使えるなど、容易に開発を行える特 徵を持っている。開発した教育システムはFig. 1に 示す。クライアントがURLを指定してサーバーにア クセスし、サーバーから送られてきたHTML・Java一 Scriptで記述された文章をBrowserが解釈する。そ

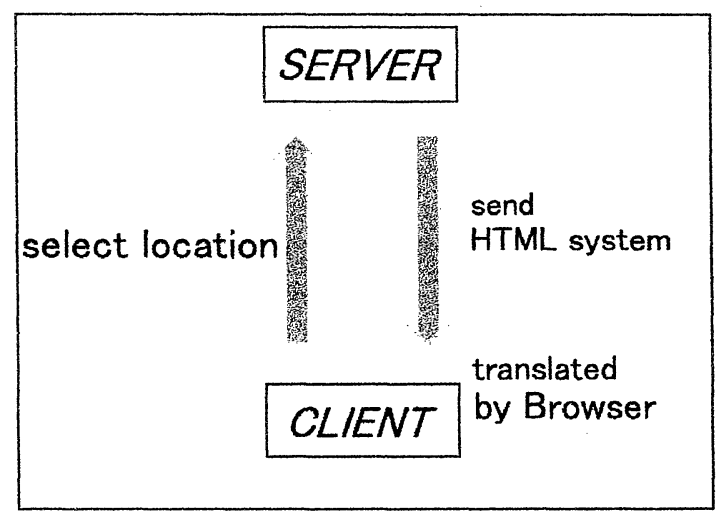

FIG. 1. CAI system on internet.

の結果が画面表示、シミュレーションの設定や解答 の正誤判断の動作となる。

\section{RESULT AND DISCUSSION}

学習方法は、「CAI Physics」システムがリン クされているホームページ上で、「CAI Physics」 をクリックし、学習状態に入る。このときシステム とデータが転送され学習者のメモリー上に展開され る。Figure 2に力学分野での画面を示す。座標の部 分は bmp ファイルで描かれ大変見やすい画面であ る。画面の右側のスクロールバーを操作するとFig. 3に示す問題画面が現れる。これは数值代入方式の 問題である。画面下方の解答欄に数值を代入して発 信すると正誤判断がなされ、CAIシステムが進行す る。問題形式は、その他に解答欄からの選択方式と レポート提出方式の出題が可能である。また、Fig. 4はVideo実験を動いている映像として画面上に再生 


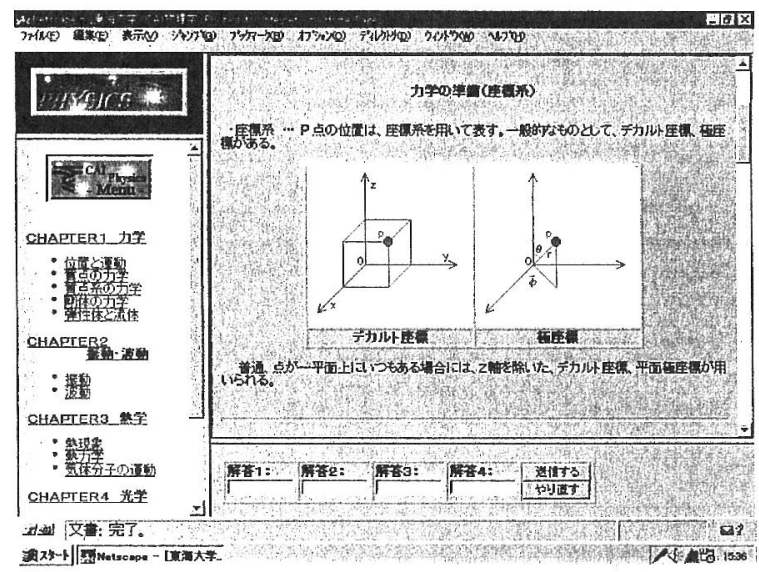

FIG. 2. Explanation Screen of "Physics for Internet".

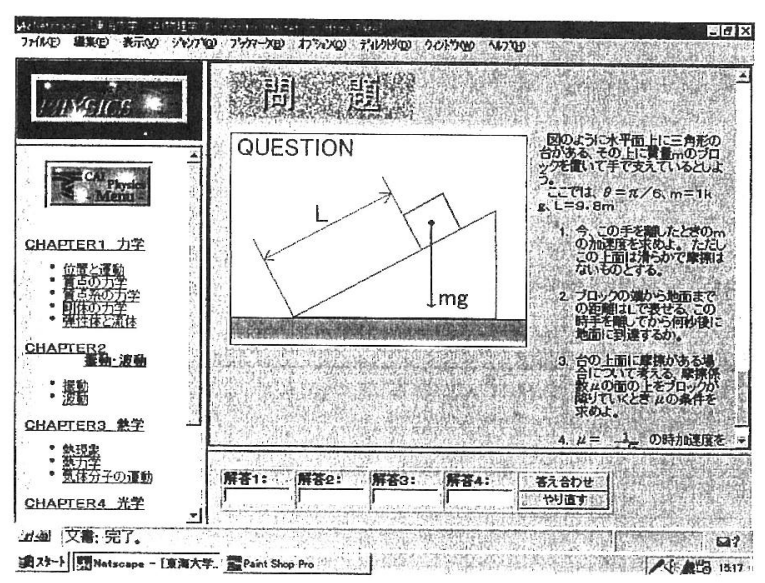

FIG. 3. Question Screen of "Physics for Internet".

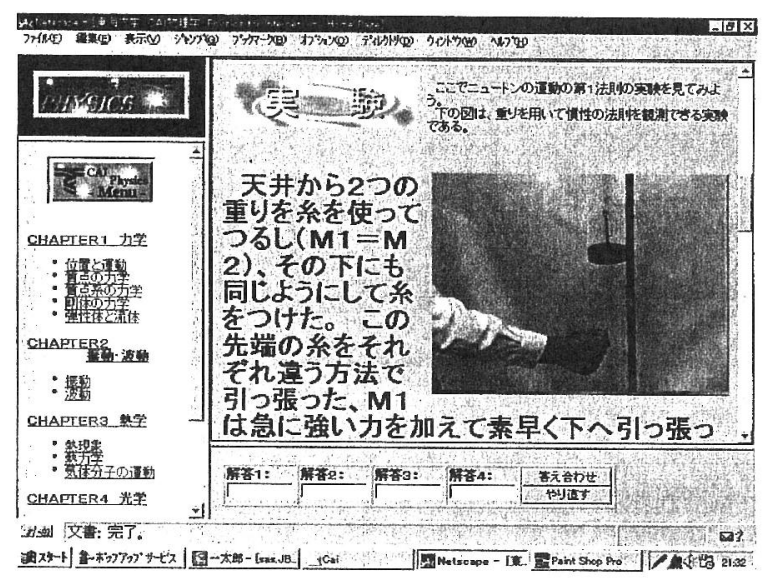

FIG. 4. Screen of experimental using VTR.
されている。このような動画は静止画と比較して印 象が強い。コースウェア一はこの画面のつながりで 構成される。このようにネットワーク上でCAIシス テムを運用することにより、学習者は場所や時間を 特定されることなく学習を進行することができる。

一般的に、インターネットにおける重要な問題点 として、データの転送速度があげられる。今回製作 したSystemは43.5MBの大きさで、通信速度は10Mbps のネットワークを使用した。午後 3 時の時点で0. $8 \mathrm{M}$ Bの大きさのファイルを転送するのに7 sec必要とし た。動画の転送速度の遅延は圧縮方法もよるが、多 人数の同時アクセスなどの通信ラインへの負荷とサ 一バー機の能力に依存する。本研究で開発したシス テムでは、利用者の学習課程等のデータ管理システ ムの開発までには至らなかったが、マルチメディア に対応したファイルの使用を可能としたことにより、 ネット上での新しいCAI環境の構築を行った。また、 リアルタイムでの音や動画像の取り扱いが可能なブ ラウザのソフトなどを追加することにより、さらに 新しい教育の可能性がある。2

\section{GONCLUSION}

本研究はインターネットで運用できるCAI教育シ ステムの開発と研究を行った。その結果、インタホットによる物理学教育は、実施されている「CAI 物理学」の延長上としても可能である。反面、問題 点も上げられる。学習者への情報と学習者からの情 報が一方的になり易く、Face to Faceから得られる 教育效果老も考慮する必要があるう。その方法の 1 つとして、時間を限定したリアルタイムでの双方向 通信による質問方式も考えられる。また、情報環境 は絶え間なく進化するため、八ードやソフト面を援 助する部局の設置が必要である。これらの問題が解 決されれば、よりインダーネットでの教育は新しい 教育方法として確立されるであるう。

\section{REFERENCES}

1 T. Suzuki and B. Kikuchi, Proc. of Inter. Conf. on Phy. Edu., 46(1995)

${ }^{2}$ M. Hosokawa, That tries CAI with an Internet., Reseach student Paper (1996 First Term)

'96 SAS Intelligent Symposium 